\title{
High Amylase Production by a Novel Strain of Bacillus amyloliquefaciens M37 Isolated from Can Gio Mangrove
}

\section{Forest, Vietnam}

\author{
Nguyen Thi Huyen My ${ }^{1(\mathbb{D})}$, Tran Thi Loan ${ }^{1(\mathbb{D})}$, Doan Van Thuoc ${ }^{1, *(\mathbb{D})}$ \\ 1 Department of Microbiology and Biotechnology, Faculty of Biology, Hanoi National University of Education. 136 Xuan \\ Thuy, Cau Giay, Hanoi, Vietnam \\ * Correspondence: thuocdv@hnue.edu.vn (D.V.T.);
}

Scopus Author ID 23471353900

Received: 13.08.2021; Revised: 15.09.2021; Accepted: 20.09.2021; Published: 16.10.2021

\begin{abstract}
Amylases are one of the most important industrial enzymes and find applications in many areas such as textiles, chemicals, food, and pharmaceuticals. Most of the amylases are derived from microbes. The objective of the present study was to evaluate amylase production by a bacterium isolated from the Can Gio mangrove forest. The bacterium was identified as a species of genus Bacillus based on morphological and biochemical characteristics. The analysis of 16S rRNA sequences was then confirmed that this strain belonged to Bacillus amyloliquefaciens species (100\% similarity). The effect of culture conditions such as temperature, $\mathrm{pH}$, and carbon sources on amylase production through shake-flask culture was investigated. Maximum amylase activity of $904 \mathrm{IU} / \mathrm{mL}$ was obtained after $24 \mathrm{~h}$ of cultivation in $\mathrm{LB}$ medium containing $1 \%$ soluble starch at $35^{\circ} \mathrm{C}$ and $\mathrm{pH} 7.0$. The highest enzyme activity of $1279 \mathrm{IU} / \mathrm{mL}$ was achieved in the bioreactor after $30 \mathrm{~h}$ of cultivation at optimum conditions. In addition, B. amyloliquefaciens M37 can grow on soybean meal medium. The high bacterial cell number of $456 \times 10^{9} \mathrm{CFU} / \mathrm{g}$ and amylase activity of $1039 \mathrm{IU} / \mathrm{g}$ were obtained after $36 \mathrm{~h}$ of cultivation. This newly isolated B. amyloliquefaciens M37 could be a potential producer for industrial amylase production and probiotics with commercial implications.
\end{abstract}

Keywords: amylase; Bacillus amyloliquefaciens; culture condition; enzyme; soybean meal.

(C) 2021 by the authors. This article is an open-access article distributed under the terms and conditions of the Creative Commons Attribution (CC BY) license (https://creativecommons.org/licenses/by/4.0/).

\section{Introduction}

Amylases are among the most important industrial enzymes and are of great significance for biotechnology [1-4]. There are three types of amylase, including $\alpha$-amylase, $\beta$ amylase, and $\gamma$-amylase. Alpha-amylase is an endo-acting enzyme, which catalyzes the hydrolysis of the $\alpha-1,4$ glycosidic linkages of starch and other polysaccharides to produce several products such as glucose, maltose, and dextrins. $\beta$-amylase is an exo-acting enzyme that attacks the substrate from the non-reducing end and hydrolyzes $\alpha-1,4$ and cannot bypass $\alpha-1,6$ linkages, thus producing maltose as a major end product. $\gamma$-amylase is an exo-acting enzyme that attacks the substrate from the non-reducing end and hydrolyzes both $\alpha-1,4$ and $\alpha-$ 1,6 linkages, thus producing glucose as a major end product $[2,4]$.

Amylases can be produced by many different organisms, including plants, animals, and microbes such as fungi and bacteria. The microbial source of amylases is preferred to other sources because microbial amylases have a wide range of advantages such as their easy production optimization process, time and space effectiveness, and cost-effectiveness [1, 3, 4]. 
Several bacteria have been shown are capable of producing a high amount of $\alpha$-amylase for industrial applications, most of them belonged to the genus Bacillus, such as $B$. amyloliquefaciens, B. subtilis, B. licheniformis, and B. stearothermophilus [1-5]

Amylases are used commercially for starch liquefaction, paper, desizing textile fabrics, in preparing starch coatings of paints, in the food industry, including baking and brewing, production of ethanol, and production of high fructose corn syrup [1-5]. These users have placed greater stress on increasing amylase production and search for more efficient producers and processes. Therefore, finding microorganisms that can produce a high quantity of amylase is an important goal of scientists [2]. In addition, microbial growth and metabolite synthesis mainly depend on the culture medium composition and cultivation conditions. Optimizing the medium composition and cultivation parameters plays a very important role in improving the microbial metabolite synthesis and minimizing the production cost [6-9].

The mangrove is a unique ecosystem located at an interface between sea and land. There is an amazing richness of microorganisms and microbial diversity (bacteria, fungi, algae, plankton, and archaea) in mangrove ecosystems. The microorganisms play an important ecological role and function in the cycling of nutrients [10]. Several studies have been focused on finding new hydrolytic enzyme producers from mangrove ecosystems [11-13]. Recently, a bacterium holding potential for high amylase production has been isolated from the Can Gio mangrove forest (Vietnam). In the present study, the isolated strain will be identified based on morphological and biochemical characteristics and subsequent molecular characterization of the 16S rRNA gene sequence. Furthermore, the cultural conditions such as temperature, $\mathrm{pH}$, and carbon sources for amylase production will be optimized using one factor at a time method. The utilization of cheap culture mediums such as soybean meal for amylase production will also be investigated.

\section{Materials and Methods}

\subsection{Bacterium maintained.}

A bacterial strain, designated M37, was isolated from the Can Gio mangrove forest (Vietnam) and used in this study. The bacterial strain was maintained in LB (Luria-Bertani) agar medium containing $(\mathrm{g} / \mathrm{L})$ : yeast extract, 5; peptone, 10, $\mathrm{NaCl}, 10$ and granulated agar, 20. The $\mathrm{pH}$ of the medium was adjusted to 7.0. The bacterium was maintained at $4^{\circ} \mathrm{C}$ in the refrigerator for routine laboratory use.

\subsection{Identification of strain M37}

Identification of selected strain was carried out according to its morphological characteristics [the shape and size of the selected bacterial strains were determined by scanning electron microscopy (SEM)] and biochemical tests (Gram staining, catalase, starch hydrolysis, gelatin hydrolysis, and casein hydrolysis) [14]. It was then confirmed by the $16 \mathrm{~S}$ gene sequence. The genomic DNA of the selected strain was extracted by Thermo Scientific GeneJET Genomic DNA Purification Kit. The 16S rRNA gene was amplified using the universal primers, 27F (5'-AGAGTTTGATCCTGGCTCAG-3') and 1492R (5'GGTTACCTTGTTACGACTT-3). Sequencing of the amplified DNA fragment was performed at 1st Base (Singapore), and the GenBank database searched for 16S rRNA gene similarities. Phylogenic analysis based on $16 \mathrm{~S}$ rRNA gene was performed with the aid of MEGA X software [15] using the neighbor-joining distance correlation method [16]. The 
almost complete sequence (about $1400 \mathrm{bp}$ ) of the 16S rRNA gene of the strain M37 was deposited in GenBank/EMBL/DDBJ databases (Accession number: MW436409) and used in the analysis.

\subsection{Effects of temperature, $\mathrm{pH}$, and carbon sources on growth rate and amylase activity.}

Strain M37 was grown on nutrient agar at $37^{\circ} \mathrm{C}$ for inoculum preparation. A loopful of the growth was transferred to a $100 \mathrm{ml}$ conical flask containing $25 \mathrm{~mL}$ LB liquid medium. The flask was incubated overnight at $37^{\circ} \mathrm{C}$ and $180 \mathrm{rpm}$ in a rotary shaking incubator. After overnight incubation, $1 \mathrm{~mL}$ of culture broth was inoculated in $250 \mathrm{~mL}$ Erlenmeyer flasks containing $100 \mathrm{~mL}$ of LB medium. To test the effect of temperature, the cultures were shaken at $180 \mathrm{rpm}$ in a shaker incubator at different temperatures $\left(30,35,40\right.$, and $\left.45^{\circ} \mathrm{C}\right)$ for $24 \mathrm{~h}$. To test the effect of $\mathrm{pH}$ value, the $\mathrm{pH}$ was adjusted from 5.0 to 8.5 by using $1 \mathrm{~N} \mathrm{HCl}$ or $1 \mathrm{~N} \mathrm{NaOH}$, and the cultures were incubated at $35^{\circ} \mathrm{C}$ for $24 \mathrm{~h}$. The effect of different carbon sources (glucose, maltose, starch, and carboxymethyl cellulose - CMC) was also tested by using LB medium ( $\mathrm{pH} 7.0$ ) containing $1 \%\left(\mathrm{w} / \mathrm{v}\right.$ ) carbon substrate; the cultures were incubated at $35^{\circ} \mathrm{C}$ for $24 \mathrm{~h}$. The supernatant of the culture after centrifugation $(10,000 \mathrm{rpm}$ for $10 \mathrm{~min})$ at $4^{\circ} \mathrm{C}$ was used for determining extracellular amylase activity. The culture broth was also used for the total viable count. All the experiments were carried out at least in duplicate.

\subsection{Batch fermentation for amylase production in the bioreactor.}

The bacterial strain was initially grown at $35^{\circ} \mathrm{C}$ in $250 \mathrm{~mL}$ flasks containing $50 \mathrm{~mL} \mathrm{LB}$ medium for $13 \mathrm{~h}$. One hundred fifty of culture medium was then used to inoculate $1.35 \mathrm{~L}$ of LB medium with $10 \mathrm{~g} / \mathrm{L}$ starch as a carbon source in a $3 \mathrm{~L}$ bioreactor. The cultivations were performed in batch mode, during which temperature was kept constant at $35{ }^{\circ} \mathrm{C}$, and $\mathrm{pH}$ was maintained at 7.0 by adding $5 \mathrm{M} \mathrm{HCl} / \mathrm{NaOH}$. Stirring velocity and aeration were maintained at $250 \mathrm{rpm}$ and $1 \mathrm{~L} / \mathrm{min}$ during the fermentation, respectively. After an initial $6 \mathrm{~h}$ of cultivation, samples were taken every $6 \mathrm{~h}$ for total viable count and amylase assay.

\subsection{Soybean meal fermentation.}

Soybean meal (okara) collected from Vinasoy company (Bac Ninh province, Vietnam) was mixed with $0.01 \mathrm{M}$ potassium phosphate buffer $(\mathrm{pH}=7)$ for obtaining the moisture content of $70 \%$. The mixtures were autoclaved at $121{ }^{\circ} \mathrm{C}$ for $30 \mathrm{~min}$. After cooling, the SBM was inoculated with $7.5 \%$ (v/w) of a culture broth of M37 containing $10^{8} \mathrm{CFU} / \mathrm{mL}$. After thorough mixing under sterile conditions, the inoculated SBM was incubated in a chamber at $37^{\circ} \mathrm{C}$. After an initial $12 \mathrm{~h}$ of cultivation, samples were taken every $6 \mathrm{~h}$ for total viable count and amylase assay.

\subsection{Amylase assay.}

Enzyme activities were determined from the amount of reducing sugar formed using the DNS (dinitrosalicylic acid) method described by Miller (1959) [17]. The reaction mixture containing $225 \mu \mathrm{L}$ of $1 \%(\mathrm{w} / \mathrm{v})$ soluble starch in $0.05 \mathrm{M}$ phosphate buffer $(\mathrm{pH} 7.0)$ and $25 \mu \mathrm{L}$ of suitable diluted enzyme solution was incubated at $50^{\circ} \mathrm{C}$ for $10 \mathrm{~min}$. The reaction was stopped by adding $375 \mu \mathrm{L}$ DNS solution followed by heating in a boiling water bath for $5 \mathrm{~min}$. The samples were cooled, and then absorbance was read at $540 \mathrm{~nm}$. Glucose was used as the 
calibration standard. One unit of the enzyme was defined as the amount of enzyme releasing 1 $\mu$ mol glucose per minute under the standard assay conditions.

\subsection{Total viable count.}

The collected samples were serially diluted with $0.9 \% \mathrm{NaCl}$ solution, and then $100 \mu \mathrm{l}$ of the diluted samples were spread on LB plates. After $48 \mathrm{~h}$ of cultivation at $35^{\circ} \mathrm{C}$, the colonies were counted, statistically analyzed, and expressed as colony-forming unit per milliliter $(\mathrm{CFU} / \mathrm{mL})[18]$.

\section{Results and Discussion}

\subsection{Identification of bacterial strain.}

The bacterial strain was first identified based on morphological and biochemical properties. Strain M37 was a Gram-positive, motile, endospore-forming, and rod-shaped bacterium with the size of $0.6-0.8 \times 1.8-2.5 \mu \mathrm{m}$ (Figure 1A). It was aerobic and positive for catalase, starch hydrolysis (Figure 1B), gelatin hydrolysis, casein hydrolysis, citrate utilization. Growth occurs with $0-8 \% \mathrm{NaCl}$ and optimal growth at $1 \% \mathrm{NaCl}$. The preliminary characteristics suggested that strain M37 belonged to the genus Bacillus. The genus Bacillus produces a large variety of extracellular enzymes, of which $\alpha$-amylase is an industrial enzyme. Several bacteria such as B. amyloliquefaciens [9], B. licheniformis [19], B. stearothermophilus [20] have been shown to be capable of producing a high amount of alpha-amylase for industrial applications.
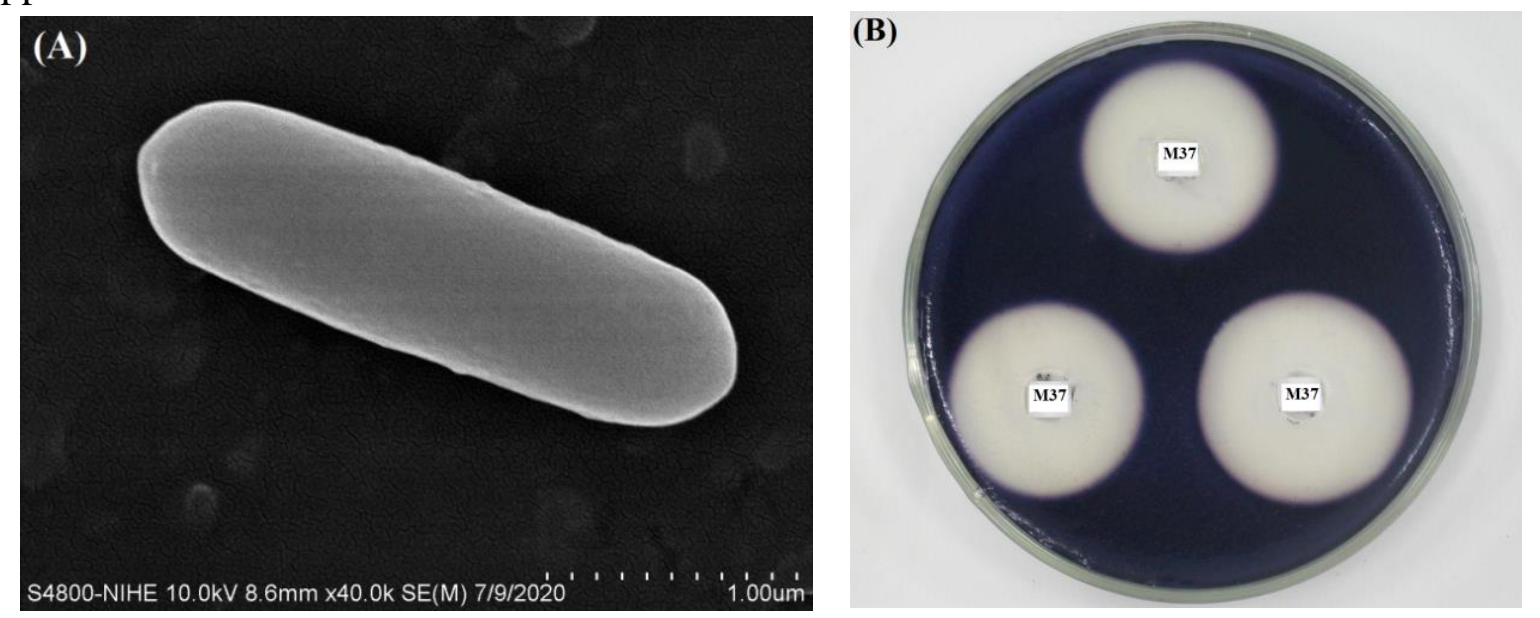

Figure 1. (A) Scanning electron micrograph of strain M37 showing its morphological features, and (B) zone of clearance due to hydrolysis of starch by strain M37.

The phylogenetic characteristic of strain M37 was then analyzed using its 16S rRNA gene sequence. The sequence of the strain M37 shared a close relationship with those of Bacillus. spp., specifically, the similarity with B. amyloliquefaciens (accession number: GQ375216) was 100\% (Figure 2). Based on 16S rRNA gene analysis, strain M37 was classed as a novel strain of B. amyloliquefaciens. B. amyloliquefaciens species can be found in various niches such as soil, plants, animal feces, and aquatic environments. The bacterial strains belonging to $B$. amyloliquefaciens species can produce various important enzymes, including $\alpha$-amylase, protease, lipase, cellulase, xylanase, pectinase, aminotransferase, barnase, peroxidase, and laccase [21]. B. amyloliquefaciens strains have also been found as promising candidate use as probiotics for animals and fishes [22-25]. 


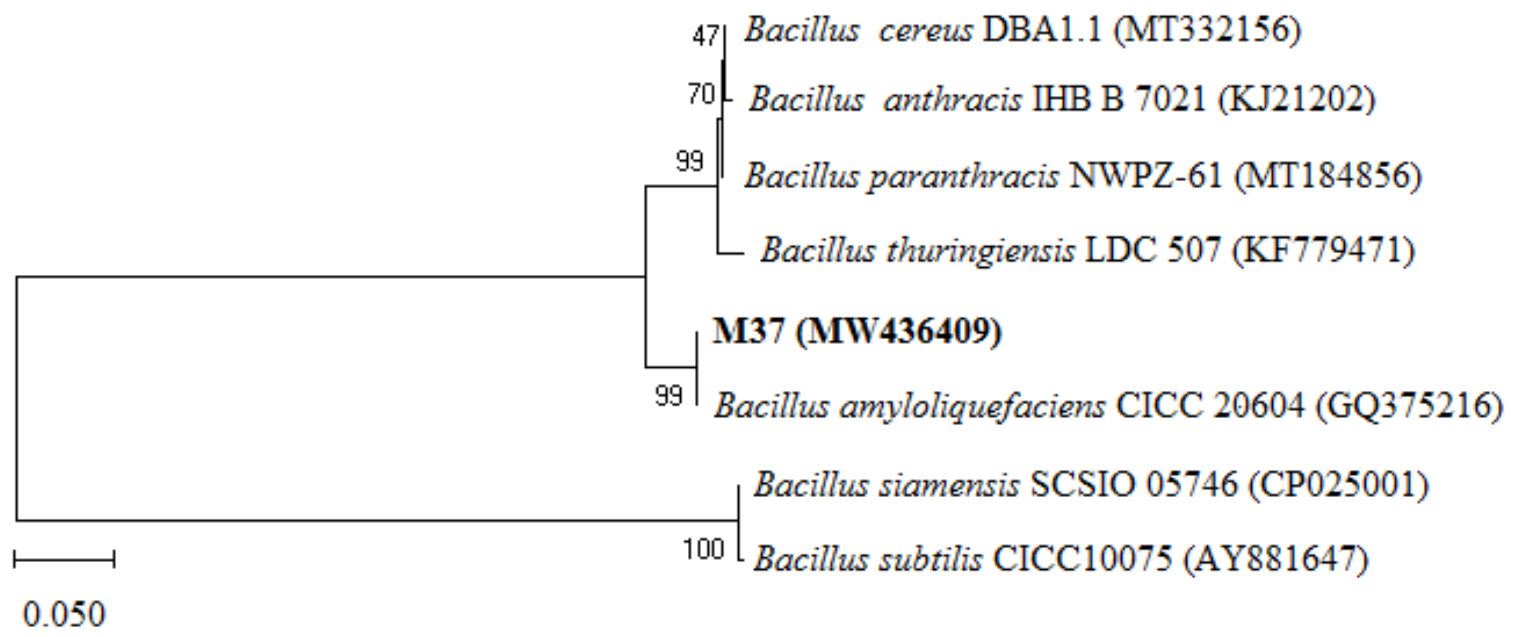

Figure 2. A phylogenetic tree based on the nucleotide sequences of the 16S rDNA, was constructed with MEGA X package using the neighbor-joining method, with bootstrap values of 1000 replicas (shown at each branch). The scale bar at the bottom indicates the number of nucleotide substitutions per site. The isolates in this study are marked with bold letters. The accession numbers are given at the end of each sequence.

\subsection{Effect of culture conditions on bacterial growth and amylase production by $B$.} amyloliquefaciens M37 in flask cultivations.

Optimization of culture conditions is very important for maximum bacterial growth and enzyme production. Among the physical and chemical parameters, temperature, $\mathrm{pH}$ value, and carbon source are the most important factors for enzyme production by bacteria [6-9].

\subsubsection{Effect of temperature.}

The influence of temperature on amylase production is related to the growth rate of the bacterium. B. amyloliquefaciens strains were reported to produce $\alpha$-amylase at a wide range of temperatures $30-60^{\circ} \mathrm{C}[6,7,9]$. In this study, to determine the optimum temperature for enzyme production, fermentation was carried out at different temperatures, $30-45^{\circ} \mathrm{C}$.

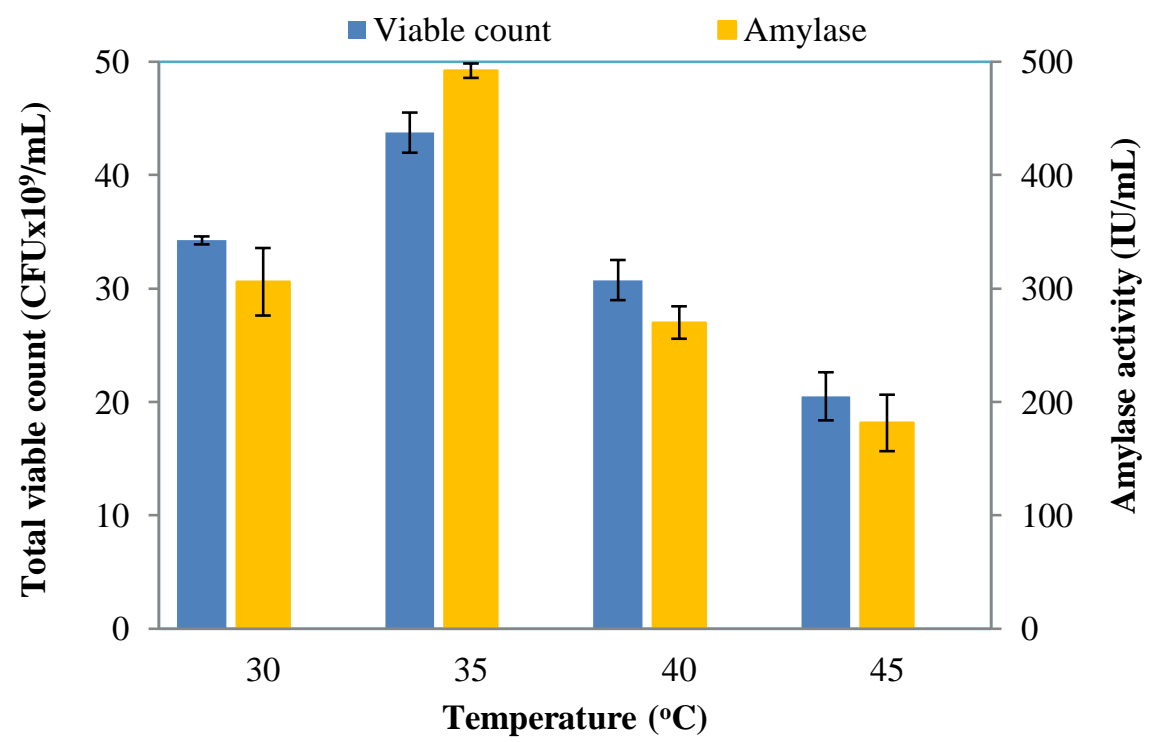

Figure 3. Effect of incubation temperature on the growth and production of amylase by B. amyloliquefaciens M37.

As shown in Figure 3, the amylase activity and bacterial growth rate were increased with increasing temperature, and maximum amylase activity of $492 \mathrm{IU} / \mathrm{mL}$ and total viable 
count of $43.8 \times 10^{9} \mathrm{CFU} / \mathrm{mL}$ were obtained at $35^{\circ} \mathrm{C}$. The enzyme activity and total viable count were then decreased when the incubated temperature increased to 40 and $45^{\circ} \mathrm{C}$. Most bacteria found in nature belong to a mesophilic group. The temperature of between $30-40^{\circ} \mathrm{C}$ is the optimal growth condition for this group. Except for some B. amyloliquefaciens strains isolated from hot or cold environments [26, 27], many previous studies reported that $\alpha$-amylase production by $B$. amyloliquefaciens species reached a maximum value at temperature $35-40^{\circ} \mathrm{C}$ $[9,28,29]$.

\subsubsection{Effect of $\mathrm{pH}$.}

The effect of different initial $\mathrm{pH}$ values (5.0-8.5) on the production of amylase by $B$. amyloliquefaciens M37 was investigated. Figure 4 shows that maximum bacterial growth rate and enzyme activity were obtained at neutral $\mathrm{pH}$ (7.0-7.5), the highest $\alpha$-amylase activity of $549 \mathrm{IU} / \mathrm{mL}$, and total viable count of $44.3 \times 10^{9} \mathrm{CFU} / \mathrm{mL}$ was reached at $\mathrm{pH} 7.0$.

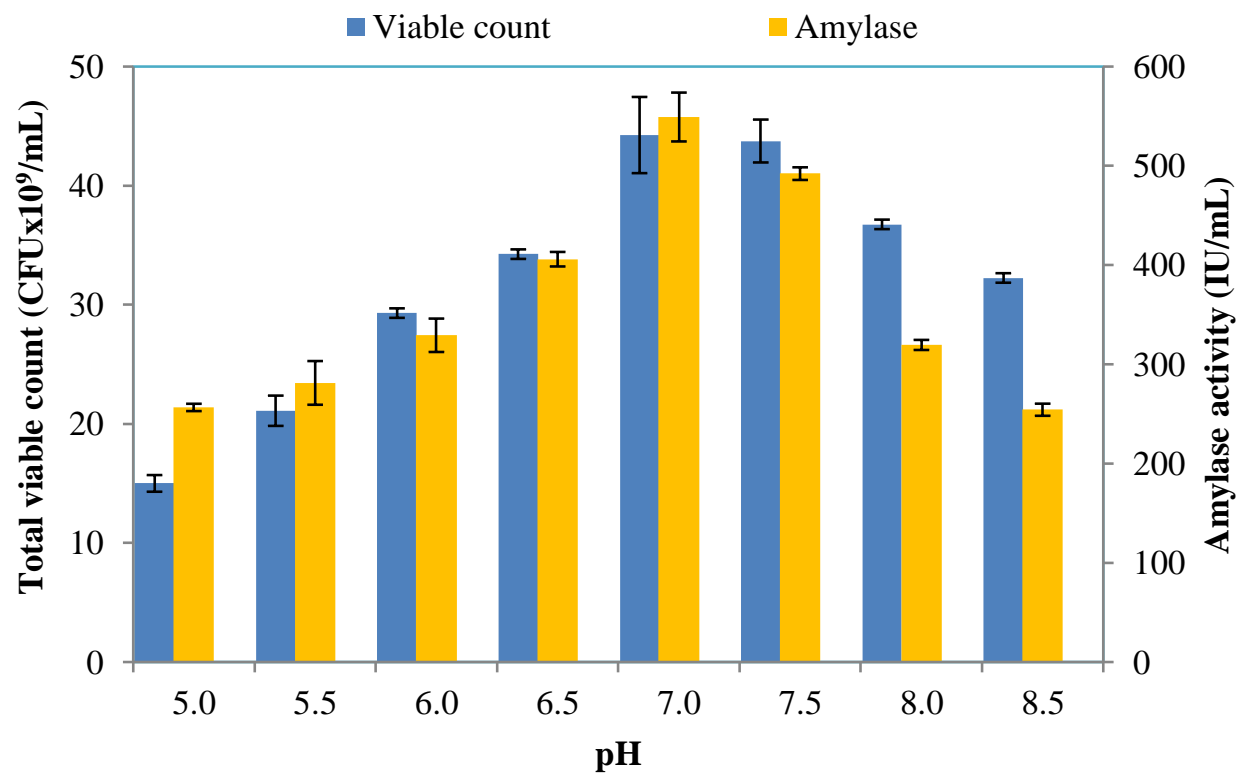

Figure 4. Effect of initial $\mathrm{pH}$ on the growth and production of amylase by B. amyloliquefaciens M37.

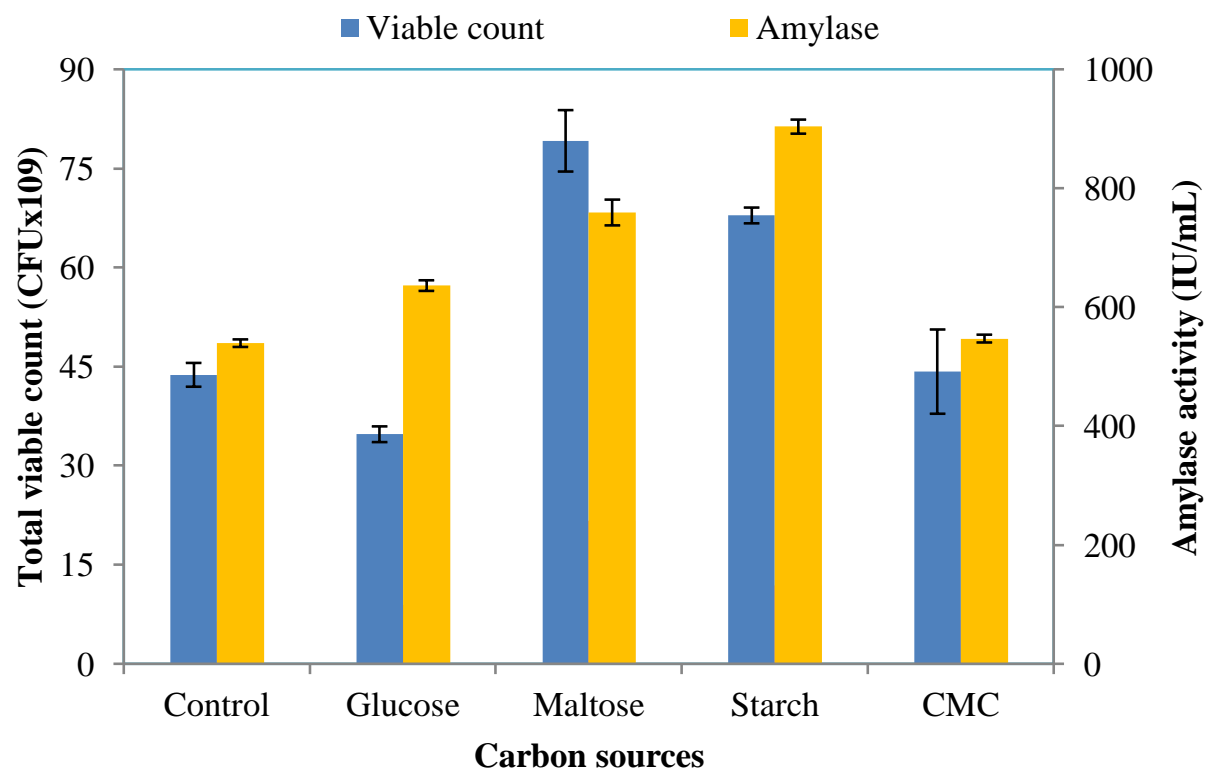

Figure 5. Effect of different carbon sources on the production of amylase by B. amyloliquefaciens M37. 
The results also indicated that high amylase activity was obtained in the acidic medium; in contrast, a high total viable count was achieved in the alkaline conditions. These results are in accordance with most of the earlier findings that revealed that the $\mathrm{pH}$ range between 6.0 and 8.0 were optimum conditions for the growth and enzyme production by B. amyloliquefaciens species $[6,29,30]$.

\subsubsection{Effect of different carbon sources.}

The number of carbon sources in culture media is an important factor for the growth and production of the enzyme [31]. The effect of different carbon sources, including glucose, maltose, starch, and CMC, on the production of $\alpha$-amylase by B. amyloliquefaciens $\mathrm{M} 37$, was tested. Maltose and starch were found to be favorable carbon sources for the growth and $\alpha-$ amylase production by strain M37, highest total viable count of $79.2 \times 10^{9} \mathrm{CFU} / \mathrm{mL}$ and amylase activity of $904 \mathrm{IU} / \mathrm{mL}$ were obtained with maltose and starch, respectively (Figure 5). Carbon sources like glucose and maltose have been used for the production of $\alpha$-amylase [9, 32], but it was found that $\alpha$-amylase activity was maximum when starch was used as the sole of carbon [3]. Besides amylase production, strain B. amyloliquefaciens M37 can also produce other extracellular enzymes such as protease and CMCase (data not shown). The production of multienzyme suggested that this bacterial strain can use low-cost substrates such as agricultural residues or food waste to produce enzymes. The biosynthesis of extracellular enzymes on agricultural residues or food waste will reduce the enzyme production cost and solve pollution problems.

3.3. The growth and enzyme production by B. amyloliquefaciens M37 in bioreactor.

The production of $\alpha$-amylase by $B$. amyloliquefaciens M37 was then investigated using batch cultivation mode in a bioreactor.

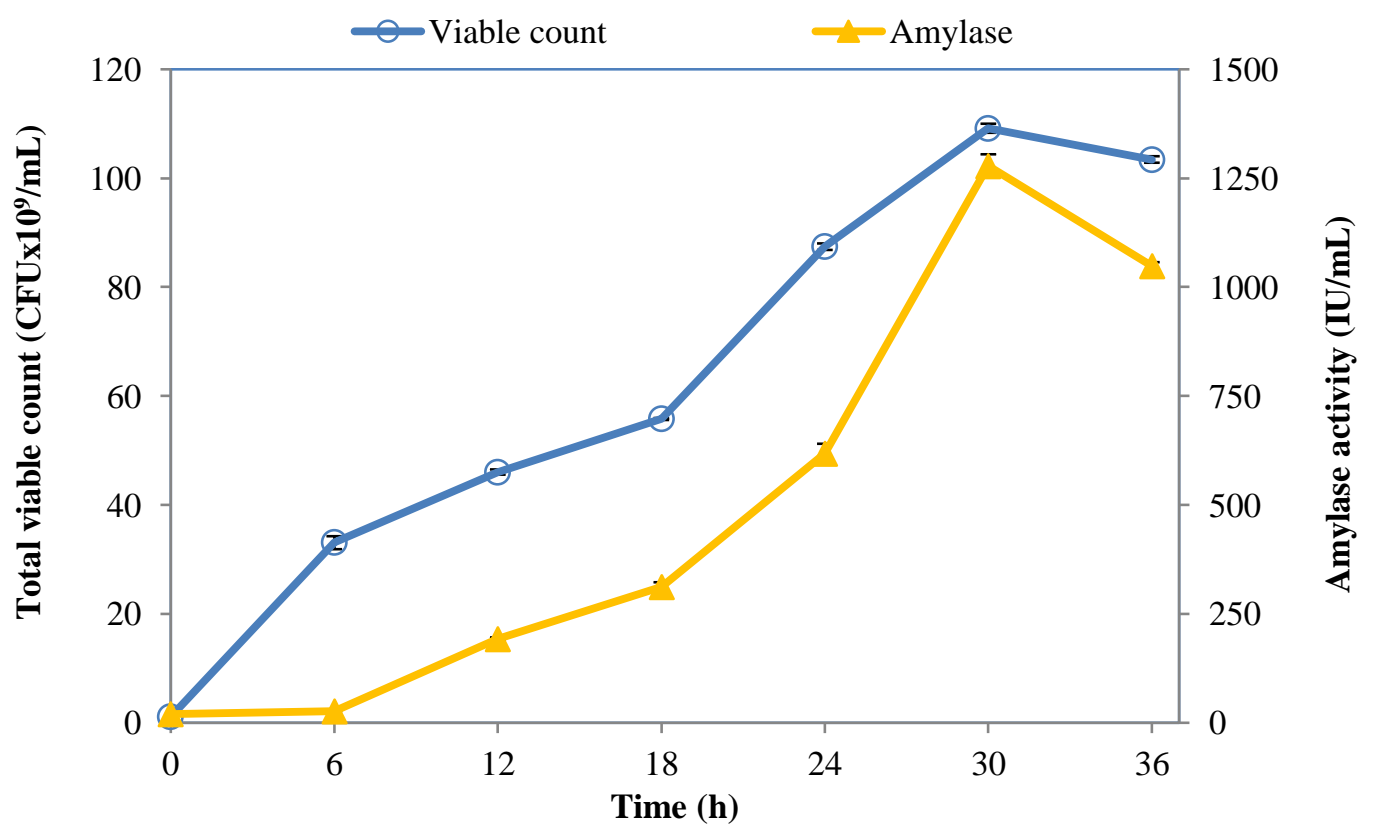

Figure 6. Time course of the growth and amylase production by B. amyloliquefaciens M37 at optimum conditions in the bioreactor.

Figure 6 shows that both total viable count and amylase activity was increased during the fermentation process and reached maximum values of $109 \times 10^{9} \mathrm{CFU} / \mathrm{mL}$ and $1279 \mathrm{IU} / \mathrm{mL}$ after $30 \mathrm{~h}$ of cultivation, respectively. In the bioreactor, cultural conditions such as $\mathrm{pH}$, 
temperature, and dissolved oxygen were maintained at optimum bacterial growth and enzyme production values. Therefore, high total viable count and amylase activity were obtained in a bioreactor and were 1.38 and 1.41 folds higher than those obtained in flask experiments, respectively.

So far, there have been some studies on the production of $\alpha$-amylase by bacteria isolated from Vietnam. Twenty-three bacteria strains were isolated from wastewater ponds at Sa Dec town, Dong Thap province by Hiep and Ly. Among them, seventeen bacterial strains exhibited high amylase activity from $72,44 \mathrm{IU} / \mathrm{mL}$ to $910,89 \mathrm{IU} / \mathrm{mL}$ (disk diffusion method) after $72 \mathrm{~h}$ of cultivation [33]. The production of amylase by Bacillus megaterium T04 isolated from the Rach Lang stream of Vietnam was investigated. Maximum amylase activity of $174.7 \mathrm{IU} / \mathrm{mL}$ was obtained after $72 \mathrm{~h}$ of cultivation in a medium containing wheat [34]. The amylase activity obtained in this study by B. amyloliquefaciens M37 $(1279 \mathrm{IU} / \mathrm{mL})$ is much higher than those obtained by other studies in Vietnam. The results obtained here are comparable to that of the high reported for $B$. amyloliquefaciens species. For example, maximum amylase activity of 64 $\mathrm{IU} / \mathrm{mL}$ was obtained by strain B. amyloliquefaciens $\mathrm{P}-001$ after $48 \mathrm{~h}$ of cultivation in a fermentation medium with initial $\mathrm{pH} 9.0$ at $42^{\circ} \mathrm{C}$ and $150 \mathrm{rpm}$ [7]. Higher amylase activity of $220 \mathrm{IU} / \mathrm{mL}$ in the case of B. amyloliquefaciens OP was achieved after $94 \mathrm{~h}$ of cultivation [9]. The highest amylase activity of $3330 \mathrm{IU} / \mathrm{ml}$ (starch-iodine method) was produced by $B$. amyloliquefaciens ATCC 23350 in the fermentation broth containing $83 \mathrm{~g} / \mathrm{L}$ peach palm flour as carbon substrate after $24 \mathrm{~h}$ of cultivation [35]. Based on the results obtained in this study, it can be concluded that B. amyloliquefaciens M37 is a good potential producer of extracellular amylase. In addition, B. amyloliquefaciens M37 was isolated from mangrove forests and grown in a wide range of $\mathrm{NaCl}$ concentrations from $0-8 \%$. The bacterial strain and its enzymes can be a good candidate for application in marine aquaculture.

\subsection{Utilization of soybean meal as a culture medium for amylase production by $B$.} amyloliquefaciens M37.

Soybean meal is commonly used as a protein source for animal feed. However, it contains anti-nutritional factors such as phytase, oligosaccharides, and trypsin inhibitors, which limit its consumption. Therefore, microbial fermentation is normally applied to improve the nutritional value of soybean meal [36]. Soybean meal has been used as a substrate for the growth of B. subtilis and B. amyloliquefaciens B-1895 under solid-state conditions. The results indicated that the soybean meal is a suitable substrate for propagating the two Bacillus species, and the fermented product can be used as a probiotic animal feed additive [37]. In another study, six Bacillus species, including three B. subtilis strains, two B. amyloliquefaciens strains and $B$. coagulans were used for feather meal-soybean meal fermentation. The fermented product was then used as a feed additive for pigs, and the results showed that fermented product has a positive effect on the growth performance and immunity of finishing pigs [38].

The present study tested soybean mean as a culture medium for bacterial cell growth and amylase production by B. amyloliquefaciens M37. As shown in Figure 6, the number of bacterial cells was increased and reached a maximum value of $456 \times 10^{9} \mathrm{CFU} / \mathrm{g}$ after $36 \mathrm{~h}$ of cultivation. The highest amylase activity of $1039 \mathrm{IU} / \mathrm{g}$ was also obtained after $36 \mathrm{~h}$ of cultivation. The results obtained in this study suggested that the fermented soybean meal produced by $B$. amyloliquefaciens M37 with sufficient amounts of bacterial cells and enzymes can be used as a potential probiotic product for animal feed. Due to the importance of this 
finding, further studies need to be done to use this fermented soybean meal product for animal feed production and applications.

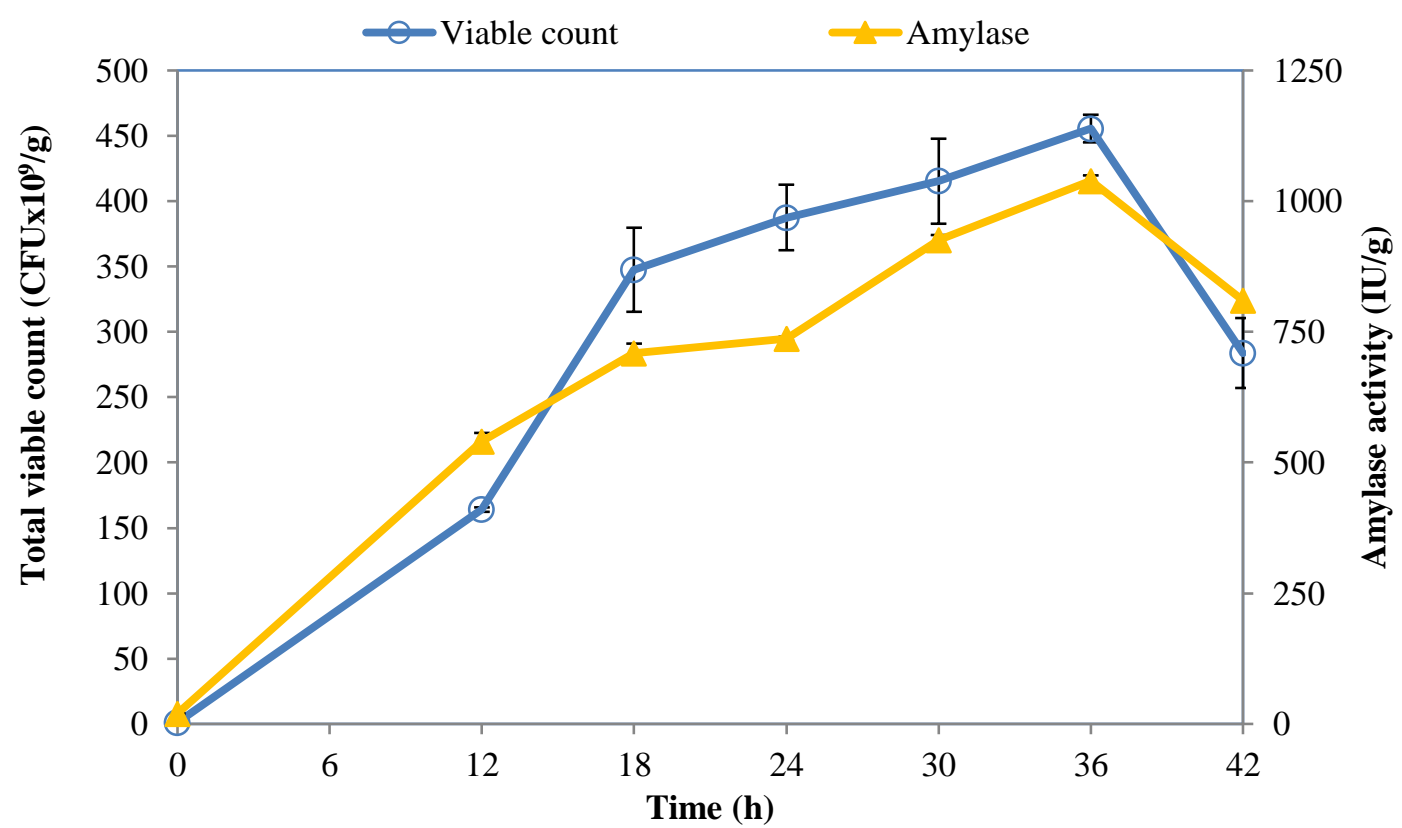

Figure 6. The number of bacterial cells and amylase activity during the fermentation process using soybean meal as a culture medium.

\section{Conclusions}

A bacterium strain M37 isolated from Can Gio mangrove forest was identified as a novel strain of $B$. amyloliquefaciens. The cultural conditions for the production of $\alpha$-amylase by $B$. amyloliquefaciens M37 have been developed in this study. The optimum enzyme production by the bacterial strain was found at $35^{\circ} \mathrm{C}, \mathrm{pH} 7.0$, and with $1 \%$ starch as a carbon source. Maximum amylase activity of $1279 \mathrm{IU} / \mathrm{mL}$ was obtained under optimum cultural conditions in the bioreactor. A high number of bacterial cells and amylase activity can also be achieved using soybean meal as a culture medium. The results obtained in the present study suggested that B. amyloliquefaciens M37 is a potential producer of amylase and probiotics, which could find commercial applications.

\section{Funding}

This research received no external funding.

\section{Acknowledgments}

The authors acknowledge the Hanoi National University of Education for providing infrastructure facilities.

\section{Conflicts of Interest}

The authors declare no conflict of interest.

\section{References}

1. Gopinath, S.C.B.; Anbu, P.; Arshad, M.K.M.; Lakshmipriys, T.; Voon, C.H.; Hashim, U.; Chinni, S.V. Biotechnological processes in microbial amylase production. BioMed Res Int 2017, 1272193, https://doi.org/10.1155/2017/1272193. 
2. Far, B.E.; Ahmadi, Y.; Khosroushahi, A.Y.; Dilmaghani, A. Microbial alpha-amylase production: progress, challenges and perspectives. Adv Pharm Bull 2020, 10, 350-358, https://doi.org/10.34172/apb.2020.043.

3. Mehta, D.; Satyanarayana, T. Bacterial and archaeal $\alpha$-amylases: diversity and amelioration of the desirable $\begin{array}{llllll}\text { characteristics for industrial applications. Front } & \text { Microbiol }\end{array}$ 1129, https://doi.org/10.3389/fmicb.2016.01129.

4. Farooq, M.A.; Ali, S.; Hassan, A.; Tahir, H.M.; Mumtaz, S.; Mumtaz, S. Biosynthesis and industrial applications of $\alpha$-amylase: a review. Arch Microbiol 2021, 203, 1281-1292, https://doi.org/10.1007/s00203020-02128-y.

5. Farias, T.C.; Kawaguti, H.K.; Koblitz, M.G.B. Microbial amylolytic enzymes in foods: technological importance of Bacillus genus. Biocatal Agric Biotechnol 2021, 35, 102054, https://doi.org/10.1016/j.bcab.2021.102054.

6. Abd-Elhalem, B.T.; El-Sawy, M.; Gamal, R.F.; Abou-Taleb, K.A. Production of amylase from Bacillus amyloliquefaciens under submerged fermentation using some agro-industrial by-products. Ann Agric Sci 2015, 60, 193-202, https://doi.org/10.1016/j.aoas.2015.06.001.

7. Deb, P.; Talukdar, S.A.; Mohsina, K.; Sarker, P.K.; Sayem, S.M.A. Production and partial characterization of extracellular amylase enzyme from Bacillus amyloliquefaciens P-001. SpringerPlus 2013, 2, 154, https://doi.org/10.1186/2193-1801-2-154.

8. Msarah, M.J.; Ibrahim, I.; Hamid, A.A.; Aqma, W.S. Optimisation and production of alpha amylase from thermophilic Bacillus spp. and its application in food waste biodegradation. Heliyon 2020, 6, e04183, https://doi:10.1016/j.heliyon.2020.e04183.

9. Uygut, MA.; Tanyuldizi, M.S. Optimization of alpha-amylase production by Bacillus amyloliquefaciens grown on orange peels. Iran J Sci Tachnol Trans Sci 2018, 42, 443-449, https://doi.org/10.1007/s40995-0160077-9.

10. Wang, Y-S.; Gu, J-D. Ecological responses, adaptation and mechanisms of mangrove wetland ecosystem to global climate change and anthropogenic activities. Int Biodeterior Biodegradation, 2021, 162, 105248, https://doi.org/10.1016/j.ibiod.2021.105248.

11. Qeshmi, F.I.; Homaei, A.; Fernandes, P.; Hemmati, R.; Dijkstra, B.W.; Khajeh, K. Xylanases from marine microorganisms: a brief overview on scope, sources, features and potential applications. Biochim Biophys Acta (BBA) Proteins Proteom 2020, 1868, 140312, https://doi.org/10.1016/j.bbapap.2019.140312

12. Kachiprath, B.; Solomon, S.; Jayanath, G.; Philip, R. Mangrove microflora as potential source of hydrolytic enzymes for commercial applications. Indian J Geo-Mar Sci 2019, 48, 678-684.

13. Ivaldi, C.; Daou, M.; Vallon, L.; Bisotto, A.; Haon, M.; Garajova, S.; Bertrand, E.; Faulds, C.B.; Sciara, G.; Jacotot, A.; et al. Screening new xylanase biocatalysts from the mangrove soil diversity. Microorganisms 2021, 9, 1484, https://doi.org/10.3390/microorganisms9071484.

14. Kersters, K.; Vancanneyt. M. Bergey's Manual of Systematic Bacteriology. Springer Verlag, 2005, pp. 3338.

15. Kumar, S.; Stecher, G.; Li, M.; Knyaz, C.; Tamura, K. MEGA X: Molecular Evolutionary Genetics Analysis across computing platforms. Mol Biol Evol 2018, 35, 1547-1549, https://doi.org/10.1093/molbev/msy09.

16. Saitou, N.; Nei, M. The neighbor-joining method: a new method for reconstructing phylogenetic trees. Mol Biol Evol 1987 4, 406-425, https://doi.org/10.1093/oxfordjournals.molbev.a040454.

17. Miller, G.L. Use of dinitrosalicylic acid reagent for determination of reducing sugar. Anal Chem 1959, 31, 426-428, https://doi.org/10.1021/ac60147a030.

18. Chen, Z.M.; Li, Q.; Liu, H.M.; Yu, N.; Xie, T.J.; Yang, M.Y.; Shen, P.; Chen, X.D. Greater enhancement of Bacillus subtilis spore yields in submerged cultures by optimization of medium composition through statistical experimental designs. Appl Microbiol Biotechnol 2010, 85, 1353-1360, https://doi.org/10.1007/s00253-009-2162-x.

19. Baltaci, M.O.; Orak, T.; Taskin, M.; Adiguzel, A.; Ozkan, H. Enhancement of amylase and lipase production from Bacillus licheniformis 016 using waste chicken feathers as peptone source. Waste Biomass Valor 2020, 11, 1809-1819, https://doi.org/10.1007/s12649-018-0468-6.

20. Ravindran, R.; Williams, G.A.; Jaiswal, A.K. Evaluation of brewer's spent grain hydrolysate as a substrate for production of thermostable $\alpha$-amylase by Bacillus stearothermophilus. Bioresour Technol Rep 2019, 5, 141-149, https://doi.org/10.1016/j.biteb.2019.01.004.

21. Ngalimat, M.S.; Yahaya, R.S.R.; Baharudin, M.M.A-a.; Yaminudin, S.M..; Karim, M.; Ahmad, S.A.; Sabri, S. A Review on the biotechnological applications of the 
operational group Bacillus amyloliquefaciens. Microorganisms 2021, 9, 614, https://doi.org/10.3390/microorganisms9030614.

22. Niu, K.-M.; Khosravi, S.; Kothari, D.; Lee, W.-D.; Lee, B.-J.; Lim, S.-G.; Hur, S.-W.; Lee, S.-M.; Kim, S.K.; Potential of indigenous Bacillus spp. as probiotic fedd supplements in an extruded low-fish-meal diet for juvenile olive flounder, Paralichthys olivaceus. $J$ World Aquacult Soc 2020, 1-18, https://doi.org/10.1111/jwas.12724.

23. Wang, B.; Zhou, Y.; Tang, L.; Zeng, Z.; Gong, L.; Wu, Y.; Li, W.-F.; Effects of Bacillus amyloliquefaciens instead of antibiotics on growth performance, intestinal health, and intestinal microbiota of broilers. Front Vet Sci 2021, 8, 679368, https://doi.org/10.3389/fvets.2021.679368.

24. Maas, R.M.; Verdegem, M.C.J.; Debnath, S.; Marchal, L.; Schrama, J.W. Effect of enzymes (phytase and xylanase), probiotics (Bacillus amyloliquefaciens) and their combination on growth performance and nutrient utilisation in Nile tilapia. Aquaculture 2021, 533, 736226, https://doi.org/10.1016/j.aquaculture.2020.736226.

25. Yang, Y.; Xia, J.; Liu, Y.; Dong, J.; Xu, N.; Yang, Q.; Zhou, S.; Ai, X. Safety evaluation for the use of Bacillus amyloliquafaciens in freshwater fish cultures. Aquac Rep 2021, 21, 100822, https://doi.org/10.1016/j.aqrep.2021.100822.

26. Panda, M.K.; Sahu, M.K.; Tayung, K. Isolation and characterization of a thermophilic Bacillus sp. with protease activity isolated from hot spring of Tarabalo, Odisha, India. Iran J Microbiol 2013, 5, 159-165.

27. Yadav, A.N.; Sachan, S.G.; Verma, P.; Saushik, R.; Saxena, A.K. Cold active hydrolytic enzymes production by psychrotrophic Bacilli isolated from three sub-glacial lakes of NW Indian Himalayas. J Basic Microbiol 2016, 56, 294-307, https://doi.org/10.1002/jobm.201500230.

28. Nusrat, A.; Rahman, S.R.; Comparative studies on the production of extracellular $\alpha$-amylase by three mesophilic Bacillus isolates. Bangladesh J Microbiol 2007, 24, 129-132, https://doi.org/10.3329/bjm.v24i2.1257.

29. Bhatt, B.; Prajapati, V.; Patel, K.; Trivedi, U. Kitchen waste for economical amylase production using Bacillus amyloliquefaciens KCP2. Biocatal Agric Biotechnol 2020, 26, 101654, https://doi.org/10.1016/j.bcab.2020.101654.

30. Kikani, B.A.; Singh, S.P. Single step purification and characterization of a thermostable and calcium independent $\alpha$-amylase from Bacillus amyloliquefaciens TSWK1-1 isolated from Tulsi Shyam hot spring reservoir, Gujarat (India). Int J Biol Macromol 2011, 48, 676-681, https://doi.org/10.1016/j.ijbiomac.2011.02.010.

31. Akcan, N. High level production of extracellular $\alpha$-amylase from Bacillus licheniformis ATCC 12759 in submerged fermentation. Rom Biotechnol Lett 2011, 16, 6833-6840.

32. Sharma, A.; Satyanarayana, T. Optimization of medium components and cultural variables for enhanced production of acidic high maltose-forming and $\mathrm{Ca}^{2+}$-independent $\alpha$-amylase by Bacillus acidicala, $J$ Biosci Bioeng 2011, 111, 550-553, https://doi.org/10.1016/j.jbiosc.2011.01.004.

33. Hiep, N.H.; Ly N.T.H. Isolation of starch degrading bacteria. J Sci Can Tho University 2012, 21a, 37-44.

34. Tu, N.; Vinh, D.; Thu, L. Amylase producing Bacillus megaterium T04 isolated in Rach Lang stream of Vietnam. J Appl Pharm Sci 2015, 5, 12-15, https://doi.org/10.7324/JAPS.2015.501003.

35. Silva, I.F.; Langbehn, R.K.; Silva, R.G.C.; Pantoja L.d.A.; Vanzela, A.P.F.C.; dos Santos, A.S. Amylase production by Bacillus amyloliquefaciens utilizing macauba cake (Acrocomia aculeata) and peach palm flour (Bactris gasipaes - kunth) as substrates. Biocatal Biotransfor 2016, 34, 76-82, https://doi.org/10.1080/10242422.2016.1227794.

36. Mukherjee, R.; Chakraborty, R.; Dutta, A. Role of fermentation in improving nutritional quality of soybean meal - a review. Asian Australas J Anim Sci 2016, 29, 1523-1529, https://doi.org/10.5713/ajas.15.0627.

37. Mahoney, R.; Weeks, R.; Zheng, T.; Huang, Q.; Dai, W.; Cao, Y.; Liu, G.; Guo, Y.; Chistyakov, V.; Chikindas, M.L. Evaluation of an industrial soybean byproduct for the potential development of a probiotic animal feed additive with Bacillus species. Probiotics Antimicrob Proteins 2020, 12, 1173-1178, https://doi.org/10.1007/s12602-019-09619-5.

38. Huang, H.-J.; Weng, B.-C.; Hsuuw, Y.-D.; Lee, Y.-S.; Chen, K.-L. Dietary supplementation of two-stage fermented feather-soybean meal product on growth performance and immunity in finishing pigs. Animals 2021, 11, 1527, https://doi.org/10.3390/ani11061527. 